\title{
A Igreja diante da cultura midiática digital: desafios, caminhos e perspectivas
}

\author{
Orientador: Abimar Oliveira de Moraes \\ Mestranda: Andréia Durval Gripp Souza \\ Área de Concentração: Teologia Sistemático-Pastoral \\ Linha de Pesquisa: Fé e Cultura
}

Estudiosos de comunicação e de tecnologia afirmam que a Internet não é meramente um instrumento, um meio, mas sim um ambiente, com uma forma de se viver própria, que expande sua configuração para outros ambientes e constrói um novo jeito de ser, de pertença, de relacionamento. As novas tecnologias possibilitam a criação de aparelhos que passaram a fazer parte da vida do homem hodierno, chegando a serem considerados uma extensão dele próprio. O ser humano já não se entende sem os meios eletrônicos de comunicação, a ponto de se sentir perdido quando esquece ou perde o celular, ou mesmo quando a conexão com uma rede sem fio não funciona. Diante dessa realidade, a Igreja é desafiada a pensar como poderá ser Sacramento da Salvação no "mundo digital" e integrar a mensagem do Evangelho a esse novo ambiente.

Esta dissertação tem como objeto de estudo a necessidade de uma mudança de perspectiva pastoral para que a Igreja possa continuar a cumprir a sua missão de comunicar o Evangelho e instaurar o Reino de Deus nos tempos atuais. É preciso pensar a ação pastoral em chave de comunicação, focada não mais nos meios, mas na cultura midiática, para que, nesse processo necessário de diálogo inculturado, aconteça a conversão pastoral da Igreja, em prol da produção de uma linguagem que seja capaz de comunicar o Evangelho e seus valores a homens e mulheres de nosso tempo.

Palavras-chave: Igreja. Pastoral. Evangelização. 